ОСОБЛИВОСТІ АНГЛОМОВНОГО ПРОФЕСІЙНО ОРІЕНТОВАНОГО МОНОЛОГУ ФАХІВЦІВ У СФЕРІ МЕДІАЦІЇ ТА ВРЕГУЛЮВАННЯ КОНФЛІКТІВ

\title{
DISTINGUISHING FEATURES OF ENGLISH PROFESSIONALLY ORIENTED MONOLOGUE OF SPECIALISTS IN THE FIELD OF MEDIATION AND CONFLICT RESOLUTION
}

Стаття присвячена проблемі навчання
англомовного просресійно орієнтованого
монологічного мовлення майбутніх фахів-
ців у сфері медіації та врегулювання кон-
орліктів. Розкриваються професійні якості
медіатора та законодавча база процесу
медіації у різних країнах світу. Досліджу-
ється становлення та розвиток медіації
в Україні.

Авторка порівнює лінгвістичні ознаки спонтанного та підготовленого монологічного мовлення, обгрунтовує використання підготовленого професійно орієнтованого монологічного мовлення під час навчання майбутніх фрахівців у сорері медіації та врегулювання конфрліктів. Мета статті - з'ясувати профресійні ознаки фрахівців у соері медіації та врегулювання консрліктів для їх подальшого зіставлення з рисами підготовленого монологічного мовлення; обірунтувати есрективність використання такого виду мовлення під час навчання майбутніх фрахівців у ссрері медіації та врегулювання консрліктів. Класифріковано ознаки професійно орієнтованого монологу, такі як: однобічний характер висловлювання, підготовленість і плановість, певна тривалість у часі, індивідуальна композиційна побудова значних за розміром уривків, композиційна завершеність і загальна структурна цілісність. Основна увага зосереджується на різновидах монологічного мовлення, які були виокремлені на основі опитування та порівняльного аналізу. Визначено низку комунікативних фуункцій, які виконує англомовне профресійно орієнтоване монологічне мовлення, а саме: інфрормативну, впливову, експресивну, ритуально-культову. Авторка зазначає, що під час відбору видів профресійно орієнтованого монологу керувалася фрункціями, які виконує медіатор: діагностичною, організаційною, освітньо-інфрормаційною, трансляційною та фоункцією примирення.

Зроблено висновок, що використання підготовленого просресійно орієнтованого монологу під час навчання майбутніх фрахівців у сорері медіації та врегулювання консрліктів $\epsilon$ невід'ємною структурною складовою частиною, яка забезпечує розвиток професійних умінь та сприяє накопиченню знань у профеесійній галузі.

Ключові слова: медіація, підготовлене англомовне професійно орієнтоване монологічне мовлення, комунікативні фуннкиї, комунікативна мета, мовні ознаки підготовленого монологу.

The article is devoted to the problem of teaching English language professionally oriented monologue speech of future specialists in the field of mediation and conflict resolution. The professional qualities of the mediator and the legal basis of the mediation process in different countries of the world are revealed. The formation and development of mediation in Ukraine is investigated.

The author compares the linguistic features of spontaneous and trained monologue speech, substantiates the use of trained professionally oriented monologue speech in the training of future specialists in the field of mediation and conflict resolution. The purpose of the article is to find out the professional characteristics of specialists in the field of mediation and conflict resolution for their further comparison with the features of the prepared monologue speech; to substantiate the effectiveness of the use of this type of speech in the training of future professionals in the field of mediation and conflict resolution. The features of a professionally oriented monologue are classified, such as: one-sided nature of expression, preparedness and timidity, definite duration in time, individual compositional construction significant excerpts, compositional completeness and overall structural integrity.

The main focus is on the varieties of monologue speech, which were distinguished on the basis of questioning and benchmarking. A number of communicative functions, which are performed by English-speaking professionally oriented monologue speech, namely: informative, influential, expressive, ritual-cult. The author notes that the selection of types of professionally oriented monologue was guided by the functions performed by the mediator: diagnostic, organizational, educational, informational, translational and reconciliation functions.

It is concluded that the use of a trained professionally oriented monologue in the training of future specialists in the field of mediation and conflict resolution is an integral structural component that ensures the development of professional skills and promotes the accumulation of knowledge in the professional field.

Key words: mediation, prepared professional English monologue, communicative functions, communicative goal, language features of the prepared monologue.
Загальновідомо, що вплив на аудиторію засобами мови - значний і дієвий, здебільшого є механізмом для досягнення поставленої мети.

Ми переконані, що навчання англомовного професійно орієнтованого монологічного мовлення має відбуватися паралельно з аналізом процесу сприйняття. На думку А.А. Леонтьєва, процесом сприйняття називається відображення у свідомості людини зовнішніх ознак предметів та явищ, що здійснюється за допомогою органів відчуття i закінчується створенням образу та подальшим його використанням $[1$, с. 76$]$.

Зауважимо, що інфрормаційний обмін - глобальне явище нашого життя, яке виходить за межі звичного профеесійного спілкування. Сутність психологічного процесу обміну інсрормацією полягає в необхідності суб'єктів мовної діяльності виробити єдину знакову систему і єдине розуміння питань 
під час спілкування. Коли фрахівець отримує інорормацію, він її насамперед інтерпретує, тобто сприймає певним конкретним чином. Це залежить як від самої інформації, так і від індивідуального досвіду особи, її знань, загального рівня розвитку. Залежно від багатьох причин фрахівці можуть зовсім по-різному зрозуміти й сприйняти одне й те ж повідомлення. Більше того, вони навіть можуть дати абсолютно протилежні оцінки одного й того ж явища, по-різному усвідомлюючи його. Тому продуктивне спілкування супроводжується зазвичай уточненнями, поясненнями, деталізацією.

Таким чином, якщо навчальний процес буде підпорядкований таким психологічним процесам і методика побудови професійно орієнтованих мовних алгоритмів буде домінантним складником, то ми досягнемо найкращих результатів у підготовці майбутніх фрахівців у сорері медіації та врегулювання конфрліктів.

Постановка проблеми у загальному вигляді. Слід зауважити, що в методиці проблема навчання англомовного професійно орієнтованого монологічного мовлення досліджувалася багатьма науковцями, серед яких - Н.Ф. Бориско, І.В. Самойлюкевич, М.С. Балабайко, В.Л. Скалкін, Л.І. Дєвіна, І.О. Зимня, Г.В. Ільїна, В.В. Єрьоміна, Г.В. Ієвлєва, Т.В. Каріх, В.І. Кунін, І.В. Рахманов, Л.Н. Смирнова, І.А. Алешко, А.А. Ємельянова, В.Л. Гаращенко. Однак навчанню майбутніх фрахівців у сорері медіації та врегулювання конфрліктів приділено не досить уваги, адже спеціалізація порівняно з іншими спеціалізаціями ЗВО нова та мало досліджена. Зокрема, були розглянуті такі питання, як комунікативні, психологічні та лінгвістичні особливості монологічного мовлення (В.Л. Скалкін, П.Б. Гуревич); композиційно-мовні форми монологічного висловлювання (Н.А. Баташов, Н.Ф. Долгалова); вивчення спонтанного монологічного мовлення (І.В. Кочергін).

Аналіз останніх досліджень та публікацій. $€$ низка праць, присвячених навчанню монологічного мовлення таких науковців, як: С.П. Мащенко (1999), В.С. Пащук (2002), О.Ю. Мощанська (2002), Н.М. Романова (2006), О.В. Асадчих (2007), М.В. Паустовська (2010), у тому числі і профресійно орієнтованого монологічного мовлення таких учених, як: П.О. Сидоренко (2003), А.А. Улумієв (2003), М.С. Багарядцева (2004), Н.Р. Петранговська (2005), Н.Л. Драб (2005), М.В. Куімова (2005), Л.В. Малетіна (2007), В.В. Тарасенко (2008), C.Е. Кіржнер (2009). Ми погоджуємося з думкою О.Б. Тарнопольського [2, 60], що в багатьох ситуаціях професійно орієнтованого спілкування монологічне мовлення (MM) є дуже важливим, адже фахівцям необхідно вміти чітко висловлювати свою точку зору, щоб переконувати слухачів, презентувати проєкти, робити доповіді, тобто постійно звертатися до різних видів ММ.
Виділення не вирішених раніше частин загальної проблеми. Погоджуючись із переконанням О.Б. Тарнапольського, ми вважаємо, що вміння професійно орієнтованого монологічного мовлення є особливо важливими для майбутніх фрахівців у сорері медіації та врегулювання конфліктів, оскільки такі спеціалісти мусять не лише мати певні знання, але й бути здатними чітко й послідовно передати їх співрозмовникові, будувати відносно довгі логічні висловлювання, описувати події, явища, аналізувати та пояснювати фракти, наводити аргументи для досягнення бажаного результату та встановлення партнерських стосунків. Зважаючи на той фракт, що Україна перебуває у стані війни, постала потреба у підготовці кваліфрікованих фрахівців з урегулювання конфрліктів.

Мета статті полягає у з'ясуванні професійних ознак фрахівців у сорері медіації та врегулювання конорліктів для їх подальшого зіставлення з рисами підготовленого монологічного мовлення; обґрунтуванні ефрективності використання такого виду мовлення під час навчання майбутніх фрахівців у сорері медіації та врегулювання конфліктів.

Виклад основного матеріалу. Заслуговує на увагу концепція професійно орієнтованого монологічного мовлення у дослідженнях Л. Арредондо, Н.Л. Грейдіної Л.О. Введенської, Л.Г. Павлової, де помічаємо, що англомовне профресійно орієнтоване монологічне мовлення набуває форми внутрішнього діалогу з аудиторією. Тобто, з одного боку, монолог є зверненням до слухачів, а 3 іншого - відбувається двостороннє спілкування, оскільки досвідчений мовець спостерігає за реакцією аудиторії та зважає на неї, обираючи ті чи інші мовні засоби.

Спершу розглянемо поняття «медіатор» та «медіація» (ч. 1 ст. 16 проєкту Закону «Про медіацію» № 3665). Визначається, що медіатором може бути фрізична особа, яка досягла двадцяти п'яти років, має вищу або професійно-технічну освіту та пройшла професійне навчання медіації, що має включати 90 академічних годин початкового навчання і 45 академічних годин навчання практичних навичок [3]. О.О. Сергієнко, медіатор та Член Комітету сімейного права «Асоціації адвокатів України», стверджує, що профресійний рівень медіатора залежить від організації (в нашому випадку 3ВО), яка здійснювала його спеціалізовану підготовку та навчання, наявність додаткових знань та навичок, необхідних у роботі. Зарубіжний досвід свідчить, що розвиток медіації неможливий без ведення реєстру.

Так, у Грузії реєстрацію медіаторів здійснює Комісія з вирішення спорів (The Georgia Commission on Dispute Resolution), в Угорщині, Болгарії, Греції, Хорватії, Італії та Австрії такий обов'язок покладений на Міністерство юстиції, в Португалії - на Генеральний директорат політики юстиції, який є 
департаментом Міністерства юстиції, у штаті Луїзіана (США) - спеціально створений комітет при Верховному суді, у Бельгії - Федеральну комісію 3 медіації, у Швеції - Національну судову адміністрацію тощо. У Республіці Польща медіатори мають бути внесені до реєстру окружного суду. Перевагами такого варіанту ведення реєстру $є$ єдиний підхід та рівень вимог до оцінювання, об'єктивність. Для того щоб майбутні фрахівці у сорері медіації в Україні могли переймати досвід зарубіжних практик, система їхнього навчання має бути виключно професійно орієнтованою.

У деяких державах, таких як Чехія, Франція та Ірландія, немає централізованого державного органу, що відповідає за ведення реєстру медіаторів. Натомість $€$ низка неурядових громадських організацій, які здійснюють цю фрункцію: Інститут медіації Ірландії, Медіаційний фрорум Ірландії, Рада адвокатів, Дублінський міжнародний арбітражний центр, Правове суспільство Ірландії та Національний Реєстр Медіаторів. У Німеччині взагалі немає жодних обмежень щодо того, хто може бути медіатором. Для цього не потрібно спеціальної освіти, певного віку чи внесення до реєстру. Доступ до цієї профресії $€$ необмеженим. Схожа ситуація і в Швеції. До особи, яка бажає стати медіатором, не ставиться жодних вимог, окрім реєстрації в реєстрі, обов'язок ведення якого покладений на Національну судову адміністрацію. Можливий варіант виконання фуунції ведення реєстру медіаторів одночасно державним органом та неурядовою організацією. Наприклад, у Румунії та Латвії за ведення реєстру медіаторів відповідає Рада Медіації. Але члени такої Ради обираються медіаторами та затверджуються Міністерством юстиції.

У Словенії реєстр медіаторів веде Міністерство юстиції (центральний реєстр медіаторів) і дві асоціації - Словенська Асоціація Медіаторів та Словенська Асоціація організацій медіації [4].

В Україні у 2002 році був зареєстрований Український центр порозуміння, який почав діяльність у сорері медіації в кримінальних справах, відновного правосуддя, розвитку громад та медіації в школах. Український центр порозуміння створив власну мережу 315 українських громадських організацій та був реорганізований в Інститут миру і порозуміння в 2012 році. Показово, що у 2006 році Міжнародна фонансова корпорація Групи Світового Банку (МФК) провела опитування серед 1200 українських компаній, яке продемонструвало певну прийнятність проєктів МФК 3 медіації в Україні. Одним із результатів реалізації дослідження стало відкриття Українського центру медіації при КиєвоМогилянській бізнес-школі. Останніми роками в Україні було зареєстровано низку організацій, які відіграють важливу роль у контексті популяризації в Україні медіації. У 2014 році було зареєстровано два важливі громадські об'єднання: Громадська спілка «Українська академія медіації» (УАМ) та громадська організація «Національна асоціація медіаторів України» (НАМУ). Найбільш потужними організаціями, створеними в період 2015-2019, є громадська організація «Львівський центр медіації», яка щорічно проводить Львівський форум медіації, громадська організація «Ліга медіаторів України 71», яка забезпечує реалізацію волонтерського проєкту із сімейної медіації у різних районах м. Києва, громадська організація «Асоціація сімейних медіаторів України», яка докладає зусиль до фрормування стандартів навчання та практики сімейної медіації [5].

Як бачимо, майбутні фрахівці мають володіти англійською мовою професійного спрямування, щоб прогнозувати ситуації та досягати бажаних результатів своєї роботи. Таким чином, навчання профресійно орієнтованого монологічного мовлення забезпечує майбутнім фрахівцям у сорері медіації та міжнародних соціальних проєктів високий кваліфікаційний рівень, фрормує особистість конкурентоспроможного фахівця.

У $3 В 0$ навчають двох видів монологічного професійно орієнтованого мовлення: підготовленого та непідготовленого (спонтанного). Підготовлене мовлення - це висловлювання, елементи якого попередньо відпрацьовуються, автоматизуються у понадфрразових єдностях, а потім репродукуються у фрормі повідомлення певної інфрормації. Непідготовлене мовлення (спонтанне) - це такий рівень володіння англійською мовою професійного спрямування, на якому мовець може без підготовки, без опори на попередньо задані мовні одиниці, без спонукання та допомоги з боку викладача використати засвоєний раніше мовний та мовленнєвий матеріал у різних комбінаціях та ситуаціях. Таке мовлення називається спонтанним. Непідготовлене, вільне і миттєво породжуване усне мовлення становить основну частину мовленнєвої діяльності та використовується у різних сорерах спілкування [6, с. 17-23].

Підготовлене усне профресійно орієнтоване монологічне мовлення - це один 3 етапів фрормування умінь непідготовленого, спонтанного мовлення. Особливість підготовленого усного мовлення проявляється у продуманості, чіткості структурної організації. Зауважимо, що до мовних ознак, характерних для підготовленого професійно орієнтованого усного мовлення, відносять: 1) фонетичні: помірний темп мовлення, невелика кількість семантично і синтаксично не зумовлених пауз, відповідність логічних пауз паузам пунктуації; 2) лексико-граматичні: чіткий розподіл на речення та синтагми, незначна кількість вставних і службових слів; 3) текстові: послідовний розвиток теми, зв'язність мовлення відповідає письмовому аналогу. Непідготовлене (спонтанне) мовлення фрормується поступово, у міру усвідомлення того, 
що сказано, що слід сказати далі, що треба уточнити чи повторити. Зокрема, мовець слідкує за логіко-композиційним, синтаксичним, а також лексико-фрразеологічним рівнями мови. Тобто стежить за тим, щоб його мова була логічна і зв'язна, підбирає слова для адекватного вираження думки. Слід зазначити, що фонетичний і морфологічний рівні мови не контролюються, а відтворюються автоматично. Саме тому спонтанному усному професійно орієнтованому монологічному мовленню властиве обмеження складності словосполучень і речень, розподіл одного речення на декілька комунікативно самостійних. Розглянемо лінгвістичні ознаки спонтанного професійно орієнтованого монологічного мовлення: 1) фронетичні: темпова неоднорідність, труднощі розчленування тексту на висловлення речення, значна поява пауз та слів-заповнювачів пауз, порушення темпорального (часового) цілісного офрормлення мовлення; 2) лексико-граматичні: поява граматично неправильних конструкцій, невідповідність співвідношення офріційно-ділової і літературної лексики, стилістичні неточності, повтори, заміна слів, хибні початки речень; 3) текстові: побудова тексту шляхом асоціацій, а не шляхом логічного розвитку.

Таким чином, розглянувши лінгвістичні ознаки двох видів мовлення, проаналізувавши фонетичні та лексико-граматичні складники підготовленого та спонтанного монологічного мовлення, а також врахувавши професійні складники майбутніх фрахівців у сорері медіації та міжнародних соціальних проєктів, ми обрали для дослідження та подальшим інструментом навчання саме підготовлене профресійно орієнтоване монологічне мовлення, адже саме такий вид мовлення характеризується логічною точністю і довершеністю, потребує продуманої підготовки та структури відтворення.

Виокремити найважливіші ознаки професійно орієнтованого монологу для подальшого розгляду його як складника навчального процесу, на нашу думку, $€$ важливим структурним компонентом цього дослідження. Отже, ознаками англомовного профресійно орієнтованого монологу є:

- однобічний характер висловлювання, не розрахований на негайну реакцію слухача (однак слід вчити майбутніх фрахівців прогнозувати реакцію, щоб уникнути так званого «ефекту якоря», коли 3 першої почутої чи побаченої інфрормації слухач робить висновки і вже далі не сприймає сказане і не здатен мислити об'єктивно, що, відповідно, призведе до небажаних наслідків);

- підготовленість і плановість (доповідь, промова тощо). Для того щоб майбутні фрахівці у сорері медіації і міжнародних соціальних проєктів досягали очікуваних результатів у своїй професії, слід вчити їх структурних компонентів публічної промови, збагачувати їхній словниковий запас профе- сійною лексикою, а також емоційно забарвленою для створення та утримання контакту з аудиторією;

- певна тривалість у часі (чіткість і часовий розподіл на важливі елементи ПОММ та деталі це те, на що слід звертати особливу увагу, адже довготривала доповідь не лише втомлює, а й зводить нанівець важливість інфрормації);

- індивідуальна композиційна побудова значних за розміром уривків - розгорнуті й складні синтаксичні побудови (пояснення складних термінів чи процесів інколи потребують яскравих прикладів чи візуального підґрунтя). Майбутні фрахівці мають володіти технікою пояснення і переконання засобами мови;

- композиційна завершеність і загальна структурна цілісність висловлювання.

Профресійно орієнтоване англомовне монологічне мовлення виконує такі комунікативні фрункції: інформативну (повідомлення нової інформації у вигляді знань про предмети і явища навколишньої дійсності, опис подій, дій, станів); функція впливу (переконання кого-небудь у правильності тих або інших думок, поглядів, переконань, дій; спонукання до дії або запобігання дії); емоційнооцінну. Ці фрункції $€$ необхідною компетентністю у роботі майбутніх медіаторів. Розглянемо детальніше низку функцій, притаманних саме підготовленому ПОММ: 1) експресивна - використання мовленнєвого спілкування для опису стану, в якому перебуває той, хто говорить, для переконливості та зняття емоційної напруженості; 2) впливова спонукання до дії чи попередження небажаної дії, переконання щодо справедливості чи несправедливості тих чи тих поглядів, думок, дій, переконань; 3) інфрормативна - виступ, що має на меті донести певну інформацію до слухача; 4) ритуально-культова - висловлювання під час ритуального обряду (інавгурація), конгресу, конференції, національного свята тощо [7, с. 25]. Кожна 3 цих функцій має свої особливі мовні засоби вираження думки, свою мету висловлювання, свого слухача.

Загальновідомо, що англомовне професійно орієнтоване монологічне мовлення характеризується активністю тільки одного комуніканта, що означає «планування і програмування не тільки одного висловлювання або речення, як, наприклад, у діалозі, «але й всього повідомлення» [8, с. 20]. Однією 3 найважливіших особливостей ПОММ майбутніх фрахівців у сорері медіації та міжнародних соціальних проектів $€$ його ситуативність, тобто фрактично зовнішні обставини, в яких відбувається спілкування: місце, час, особистість партнера (партнерів), соціальні ролі співрозмовників тощо.

3 мовної точки зору монологічне мовлення характеризується структурною завершеністю речень, відносною повнотою висловлювання, розгорнутістю та різноструктурністю фрраз. Крім того, йому властиві також досить складний синтаксис, 
а також зв'язність, що передбачає володіння мовними засобами. Такими засобами виступають лексичні та займенникові повтори, сполучники та сполучникові прислівники, прислівники або сполучення іменника з прикметником у ролі обставини місця та часу, артиклі тощо.

Наприклад, адвербіалії часу та послідовності: later that; адвербіалії причин та наслідку: why, that is why, so, at first, so that... Як сполучні засоби в монолозі вписуються також усномовленнєві фрормули, які допомагають почати, продовжити чи закінчити професійно орієнтовне висловлювання: to begin with, well, let's leave it at that; а також показують ставлення того, хто говорить; to my mind, there is no doubt, in the conviction that, people say, because of that. На думку Д.Х. Баранника, мінімальною структурною одиницею ПО монологу $€$ переважно повне багатоскладове речення. Дослідження усного спонтанного монологічного мовлення дають змогу говорити і про окремі його лексичні особливості. Перш за все йдеться про набір окремих усно-мовленнєвих кліше, за допомогою яких розповідачі починають, продовжують чи закінчують свою розповідь (to begin with; well; to continue; let's leave it at that; I would like to tell you this); «вплітають» свою монологічну репліку в діалог (that reminds me; by the way); вводять у свій монолог елементи особистого ставлення до того, про що розповідають (fortunately; strange enough but; it seems to me). Ціла група слів і словосполучень дає змогу розповідачеві систематизувати роздуми, що містяться в його розповіді (therefore; that's why; because of that; in short). Для навчання англійської мови професійного спрямування актуальними є два стильові регістри усної мови: нейтрально-розмовний та інорормативний [9, с. 140].

Згідно 3 комунікативною метою розрізняють такі професійно орієнтовні монологічні висловлювання:

1) за метою висловлювання: монолог-повідомлення, монолог-опис, монолог-міркування, монолог-оповідання, монолог-переконання.

Проведене опитування серед фрахівців у сорері медіації та врегулювання конфліктів дало змогу виокремити найбільш вживані різновиди ПОММ (рис. 1).

Таким чином, зразками для створення навчальних моделей ми обрали монолог-міркування, монолог-переконання та монолог-опис.

Під час відбору видів ПОММ ми керувалися функціями, які виконує медіатор, а саме: діагностичну, організаційну, освітньо-інформаційну, підтримуючу, трансляційну та функцію примирення.

Висновки. Отже, у процесі зіставлення та порівняння лінгвістичних ознак двох видів мовлення, аналізу фонетичних та лексико-граматичних складників підготовленого та спонтанного монологічного мовлення було обґрунтовано доцільність
Використання ПОММ за метою висловлювання

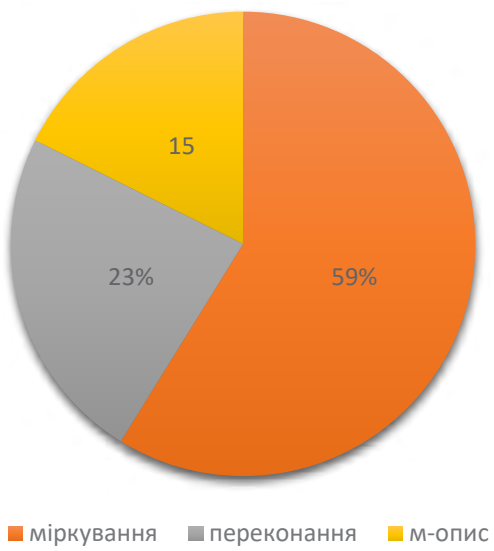

Рис. 1. Частотність використання ПОММ

використання у процесі навчання саме підготовленого професійно орієнтованого монологу для навчання майбутніх фрахівців у сорері медіації та врегулювання конолліктів. У статті акцентується увага на фрункціях, притаманних підготовленому ПОММ, а саме: експресивній, впливовій; інформативній; ритуально-культовій, а також на функціях, що виконує фрахівець 3 медіації. Проаналізовано взаємозв'язок таких функцій.

Профресія медіатора базується на комунікативному підході, що передбачає володіння навичками монологічного мовлення у профресійній сорері. У статті наведено приклади мовних кліше, які $€$ структурним компонентом англомовного професійно орієнтованого монологу.

\section{БІБЛІОГРАФІЧНИЙ СПИСОК:}

1. Леонтьев А.А. Психолингвистические единицы и порождение речевого высказывания. Москва, 1969. 307 с.

2. Тарнопольский О.Б. Методика обучения английскому языку для делового общения : учебное пособие / О.Б. Тарнопольский, С.П. Кожушко. Киев : Ленвит, 2004. 192 с.

3. URL: https://protocol.ua/ua/hto_takiy_ profesiyniy_mediator_v_nashiy_dergavi/

4. Анна Лиско, Назар Коршівський. URL: http://www.mediation.lviv.ua/?p=355).

5. Підр. Медіація у професійній діяльності юриста. Ст. 78.

6. Бондарко Л.В. Спонтанная речь и организация системы языка. Бюллетень фронетического фонда № 8. «Фонетические свойства русской спонтанной речи». / Под ред. Л.В. Бондарко, М. Краузе. СанктПетербург : Бохум, 2001. С. 17-23.

7. Скалкин В.И. Основы обучения устной иноязычной речи. Москва. 1981. 123 с.

8. Гальскова Н.Д. Теория обучения иностранным языкам: лингводидактика и методика : учебное пособие. Москва, 2004. 336 с.

9. Підручна 3. Навчання спонтанного монологічного мовлення. Наукові записки. Серія «Педагогіка». 2006. № 4, с. 140. 